Marta Wróblewska

Gdańska Galeria Güntera Grassa

ORCID: 0000-0002-4184-7975

\title{
Gdańskie instytucje kultury jako miejsca (jakiej?) pamięci
}

DOI: https://doi.org/10.26881/porta.2018.17.11

W poniższym tekście podejmuję próbę przedstawienia zarysu obecnego stanu zjawisk związanych z procesem budowania postkomunistycznej tożsamości kulturowej Gdańska w odniesieniu do lokalnej pamięci i dziedzictwa kulturowego oraz w kontekście praktyk wybranych gdańskich instytucji kultury. Przez „instytucje kultury” rozumiem te jednostki, które poprzez swoją działalność poddają muzealizacji zjawiska definiujące pamięć kulturową Gdańska i gdańszczan. Zaliczam do nich nie tylko muzea, lecz także te placówki, które nie działając w oparciu o ustawę o muzeach, posiadają własne kolekcje i wystawy stałe, za pomocą których prezentują narracje związane z pamięcią ${ }^{1}$.

Mówiąc o kształtowaniu pamięci kulturowej oraz związanej z nią tożsamości zbiorowej danego miasta czy regionu, należy jednocześnie myśleć o całej strategii tworzenia i rozwijania tzw. kultury pamięci. Nierozerwalną jej częścią jest powstawanie wielorakich i ogólnodostępnych instytucji, w tym muzeów, pomników, a także uroczystości upamiętniających ${ }^{2}$. Częściami składowymi tej działalności są także profilowanie dziedzictwa kulturowego przez władze lokalne, gromadzenie kolekcji i prezentowanie określonych narracji w ramach publicznych instytucji kultury.

Nadrzędna rola upamiętniania związana $\mathrm{z}$ działalnością wielu gdańskich instytucji kultury zachęca do postrzegania ich, za Janem Assmannem, jako "miejsc pamięci" (termin lieux de mémoire wprowadzony przez Pierre’a Norę) bądź też „figur (czy obrazów) pamięci”, za Mauricem Halbwachsem (Erinnerungsbilder, czasami także w polskich przekładach występujących jako „wspomnienia-obrazy”4). Według Nory miejsca pamięci odgrywają jednocześnie rolę materialną, symboliczną i funkcjonalną ${ }^{5}$. Autorzy leksykonu

1 M.in. Europejskie Centrum Solidarności, Gdańska Galeria Güntera Grassa, Dom Daniela Chodowieckiego i Güntera Grassa.

2 Aleida Assmann, Wprowadzenie: o krytyce, popularności i adekwatności terminu „pamięć” [w:] Między historiq a pamięcią. Antologia, red. Magdalena Saryusz-Wolska, Warszawa 2013, s. 9.

3 Jan Assmann, Pamięć kulturowa. Pismo, zapamiętywanie i polityczna tożsamość w cywilizacjach starożytnych, tłum. Anna Kryczyńska-Pham, red. Robert Traba, Warszawa 2016, s. 157.

4 Maurice Halbwachs, Społeczne ramy pamięci, przeł. Marcin Król, Warszawa 1969, s $154-155$.

5 Pierre Nora, Entre mémoire et histoire. La problématique des lieux [w:] Les Lieux de mémoire, t. 1, La République, red. Pierre Nora, Paryż 1984, s. 34. 
Marta Modi Memorandi podkreślają rosnącą tendencję, zwłaszcza we Francji i NiemWróblewska czech, do nazywania muzeów miejscami pamięci. Zwracają uwagę na istotny fakt, iż „miejsce pamięci” w pojmowaniu Nory nie musi dotyczyć jedynie topografii, lecz może także obejmować wydarzenia, procesy, postacie, artefakty mające znaczenie dla formowania dziedzictwa kulturowego ${ }^{6}$. Ten szeroki zakres definicji miejsca pamięci bardzo dobrze odzwierciedlają profile wielu gdańskich instytucji kultury, wśród których znajdziemy zarówno jednostki upamiętniające dane miejsca, jak i poświęcone wybranym wydarzeniom czy postaciom istotnym dla bardzo specyficznej pamięci kulturowej miasta.

W kontekście samego Gdańska niezwykle skomplikowanym i wielopłaszczyznowym zadaniem jest bowiem odniesienie się do lokalnej pamięci związanej z dziedzictwem kulturowym, w którym - przynajmniej w epoce nowoczesnej - ważną rolę odgrywały nie tylko podobieństwa, lecz także różnice kulturowe. Ta swoista palimpsestowość gdańskiej kultury jako kultury pogranicza i kultury różnic $^{7}$ zaczyna być powoli dostrzegana w obszarze socjologii i kulturoznawstwa ${ }^{8}$. Dyskurs odbywający się na polu kultury pozostaje w ścisłym związku z pytaniami dotyczącymi kwestii tożsamości, dla których naturalną platformą są instytucje kultury9. Postrzeganie ich jako swoistych miejsc pamięci narzuca na nie dość odpowiedzialną społecznie i kulturowo rolę. Jako takie przedstawiają wszakże określone historie za pomocą wybranych przez siebie retoryk i strategii. Ich kolekcje, stanowiące bezpośrednie źródło dla prezentowanych wystaw, niewątpliwie odzwierciedlają coraz bardziej polifoniczny dyskurs na temat tożsamości i pamięci miasta. Ten rodzaj praktyk powiązać można z ćwiczeniem pamięci, o którym pisał Paul Ricoeur ${ }^{10}$. Ćwiczenia tego rodzaju przeprowadzane są wewnątrz instytucji kultury zarówno poprzez posługiwanie się przedmiotami - w tym przypadku artefaktami pochodzącymi z ich kolekcji, jak i przestrzeniami - czyli samymi budynkami mieszczącymi ich siedziby bądź miejscami stanowiącymi symbole same w sobie w ramach topografii danego miasta. Owe miejsca, jak chce Sławomir Kapralski, są , składnicami pamięci i bodźców wyzwalających wspomnienia”. Przez to wchodzą w sojusz z samym pojęciem tożsamości, kreując „obszary stałości i ciągłości”, które zapewniają danej społeczności poczucie „bezpieczeństwa ontologicznego”"11.

Dopiero koniec okresu zimnej wojny, jak dowodzi Robin Ostow, zaznaczył przełom w polityce tożsamościowej Europy, dopuszczając do głosu przedstawicieli

6 Modi memorandi. Leksykon kultury pamięci, red. Magdalena Saryusz-Wolska, Robert Traba, Warszawa 2014.

7 Por. Homi K. Bhabha, Culture's In-Between [w:] Questions of Cultural Identity, red. Stuart Hall, Paul du Gay, London-Thousand Oaks-New Dehli 1996, s. 54-55.

8 Por. m.in. Pomorska debata o kulturze: kultura na pograniczu - pogranicza kultury, red. Cezary Obracht-Prondzyński, Katarzyna Kulikowska, Gdańsk 2014.

9 Paul du Gay, Organizing Identity: Entrepreneurial Governance and Public Management [w:] Questions of Cultural Identity..., s. 152.

10 Paul Ricoeur, Pamięć, historia, zapomnienie, przeł. Janusz Margański, Kraków 2007, s. 77.

11 Sławomir Kapralski, Pamięć, przestrzeń, tożsamość. Próba refleksji teoretycznej [w:] Pamięć, przestrzeń, tożsamość, red. Sławomir Kapralski, Warszawa 2010, s. 9-10. 
wielu wykluczonych grup, funkcjonujących w nowym demokratycznym świecie już nie jako anonimowe jednostki, ale jako aktywni obywatele, dla których agorą stały się także muzea, zmuszone do zrewidowania swoich tradycyjnych struktur i działalności ${ }^{12}$. Polska, w tym zwłaszcza miasta przyłączone do niej po 1945 r., stanęła przed bardzo specyficznymi dylematami dotyczącymi kierunków kształtowania własnej pamięci i tożsamości kulturowej. W szczególności ciekawy jest profil społeczny Gdańska, który po 1945 r. budowany był niemal od podstaw przez polskich przybyszów. Nie dzielili oni żadnej pamięci z garstką pozostałych po wojnie autochtonów gdańskich, lecz przywieźli ze sobą własne lokalne pamięci, charakterystyczne dla miejsc, z których pochodzili ${ }^{13}$. Naturalnie rozpoczęli oni proces „oswajania” z miastem po 1945 r., m.in. poprzez podkreślanie jego związków z Polską - był to kierunek, któremu sprzyjała także polityka kulturalna ówczesnych władz ${ }^{14}$

Bezsprzecznie symboliczna wydaje się cezura roku 1989 - istotnego nie tylko ze względu na zmianę systemu politycznego, lecz także w dużej mierze ze względu na zmianę warunków społecznych, gospodarczych i kulturowych. Jak słusznie zauważa Marta Karkowska w swoich rozważaniach nad pamięcią kulturową Olsztyna, „stosunkowo niedawna zmiana ustrojowa, mająca wpływ także na skład i działalność władz lokalnych, wymusiła zdefiniowanie i opisanie na nowo wizji przeszłości miasta" ${ }^{15}$. To stwierdzenie jest prawdziwe również dla Gdańska. Zmiana ta umożliwiła szerszą refleksję i dyskusję, a w końcu wprowadzanie stopniowych modyfikacji do dotychczas jednowymiarowej narracji dotyczącej pamięci i ściśle z nią związanej tożsamości kulturowej, kreowanej m.in. w ramach instytucji kultury ${ }^{16}$. Procesy te stanowią nie tylko istotną część debaty publicznej odbywającej się wśród odbiorców narracji prezentowanych w instytucjach kultury, lecz są także przedmiotem polityk kulturalnych władz, z którymi te instytucje pozostają w zależności organizacyjnej i finansowej.

Należy jeszcze raz podkreślić, iż proces ten wydaje się szczególnie istotny w Gdańsku, gdzie ciągłość nowej pamięci na szerszą skalę zaczęto konstytuować dopiero w czasach powojennych, a w nieskrępowanym wydaniu właśnie po roku $1989^{17}$. Stąd też nierzadko mechanizmy jej budowania przypominają w pewnym

12 Robin Ostow, Introduction: Museums and National Identities in Europe in the Twenty-First Century [w:] Revisualizing National History, red. Robin Ostow, Toronto, 2008, s. 3-4.

13 Por. Stefan Chwin, Mity i prawdy nowej gdańskiej pamięci [w:] Gdańskie tożsamości. Eseje o mieście, red. Basil Kerski, Gdańsk 2014, s. 223.

14 Jacek Friedrich, Polskość? Niemieckość? Gdańskość? O tożsamości sztuki i architektury Gdańska w XIX i XX wieku [w:] Gdańskie tożsamości..., s. 181; idem, Odbudowa Głównego Miasta w Gdańsku w latach 1945-1960, Gdańsk 2015, s. 55-81.

15 Marta Karkowska, Pamięć kulturowa mieszkańców Olsztyna lat 1945-2006 w perspektywie koncepcji Aleidy i Jana Assmannów, Warszawa 2014, s. 227

16 Ibidem, s. 13-17.

17 Warto jednak wskazać, że proces konstruowania tej nowej, polskiej pamięci w odniesieniu do Gdańska rozpoczął się już w okresie międzywojennym, por. Jacek Friedrich, Walka obrazów. Przedstawienia wobec idei w Wolnym Mieście Gdańsku, Gdańsk 2018, s. 204-297. 
Marta sensie to, co Eric Hobsbawm opisuje jako inventing traditions (wymyślanie traWróblewska dycji). Ich charakterystyczną cechą jest to, że zostały skonstruowane w miarę niedawno, w dość szybkim tempie. Częstokroć bazują na znanych i oswojonych zdarzeniach z przeszłości. Dzięki temu poddają teraźniejszość swoistej rytualizacji w odniesieniu do przeszłości oraz podkreślają związki z nią w sposób powtarzalny i ciągły. To zaś sprzyja ugruntowaniu i legitymizowaniu trwałych i stabilnych elementów życia społecznego ${ }^{18}$.

Wymyślanie tożsamości niejako od nowa pozostaje w ścisłym związku z lokalnym mitotwórstwem mającym za zadanie tworzenie nowej pamięci, w której można by się komfortowo odnaleźć. Trzy naczelne mity związane z pamięcią Gdańska wylicza Peter Oliver Loew, a są nimi: niemieckość, polskość i wielokulturowość. O ile pierwsze dwa badacz przypisuje historycznym interesom politycznym m.in. Królestwa Pruskiego oraz Polski Ludowej, o tyle trzeci mit, w jego przekonaniu, jest konstruktem obecnej polityki kulturalnej, promowanej przez elity polityczne i naukowe miasta. Stanowi on rodzaj działania rekompensującego, będącego z jednej strony parasolem dla zbioru wybranych wydarzeń nadających ciągłość i wiarygodność historyczną gdańskiej tożsamości, a z drugiej strony alternatywą dla zdezaktualizowanych mitów polskości i niemieckości $^{19}$. Lesław Michałowski zauważa, że mity kulturowe, wykreowane w dużej mierze z czynnym udziałem przedstawicieli władz lokalnych, są znaczącą częścią struktury gdańskiej tożsamości lokalnej, i tłumaczy to w następujący sposób: „Istnieją społeczne oczekiwania wobec przeszłości, to naprzeciw nim wychodzi coś, co nazwać można historią praktyczną - historią, której sens nadaje związek przeszłości z doświadczeniem bieżącym” ${ }^{20}$. Człowiek myśląc o przeszłości, patrzy na zabytki i miejsca w przestrzeni miasta, gdzie przeszłość powinna mu się kojarzyć z teraźniejszością i tę teraźniejszość jednocześnie wyjaśniać. Jak twierdzi badacz: „Ten proces wspierany jest przez mit”"21. Oczywiście należy podkreślić za Michałowskim, że kształt tworzonych mitów miasta zależy od rodzaju jego pamięci zbiorowej, co niewątpliwie przekłada się na charakterystykę jego tożsamości kulturowej. O specyficznej dla Gdańska płynnej tożsamości, paradoksach $\mathrm{w}$ świecie kultury oraz związanej z tym pluralizacji działań praktykowanych przez instytucje kultury będące narzędziem realizacji lokalnej polityki kulturalnej piszą autorzy opracowania Poszerzenie pola kultury. Diagnoza potencjału sektora kultury w Gdańsku. W odniesieniu do Gdańska mówią oni o tożsamości typu insert (termin zaczerpnięty od Wojciecha Burszty i Piotra

18 Eric Hobsbawm, Wprowadzenie: Wynajdywanie tradycji [w:] Tradycja wynaleziona, red. Eric Hobsbawm, Terence Ranger, przeł. Mieczysław Godyń, Filip Godyń, Kraków 2008, s. 9-13.

19 Por. Peter Oliver Loew, Trzy mity. Niemieckość, polskość, wielokulturowość [w:] Gdańskie tożsamości..., s. 133-141; idem, Historia szuka pamięci [w:] Gdańskie tożsamości..., s. 155.

20 Lesław Michałowski, Trójmiasto. Jedna przestrzeń, trzy mity [w:] Pamięć, przestrzeń, tożsamość, red. Sławomir Kapralski, Warszawa 2010, s. 258.

${ }^{21}$ Ibidem. 
Majewskiego) - „otwartej na propozycje i gotowej włączyć »wszelkie dostępne materiały, pochodzące na równi z doświadczeń przeżytych, jak i medialnych, jeżeli mogą one, na określony czas, warunkowo « stworzyć koherentną całość"22.

Z powyższych rozważań jasno wynika, że kształt pamięci kulturowej definiującej miejsca pamięci związane $\mathrm{z}$ danym miastem pozostaje $\mathrm{w}$ znacznej zależności z założeniami polityki kulturalnej kształtowanej przez lokalne władze. To one są bowiem odpowiedzialne za formułowanie strategii rozwoju miasta, której priorytetami są zawsze kultura i związana z nią pamięć. To przecież władze lokalne w dużej mierze nadają statuty organizowanym przez siebie instytucjom kultury, definiując obszary ich zainteresowań i działalności. Ciekawą perspektywę postrzegania stosunku narracji instytucji funkcjonujących na polu kultury do polityki i władzy przedstawiają tacy badacze, jak Tony Bennet czy Tomasz Szkudlarek i Zbyszko Melosik ${ }^{23}$. Ich analiza ma swoje źródło w rozważaniach Michela Foucault, według którego funkcjonowanie muzeów - również w sensie wywierania wpływu na konstruowanie i dyscyplinowanie tożsamości - jest ściśle związane z aparatami władzy produkującymi wiedzę i sprawującymi kontrolę nad aranżowaniem i postrzeganiem rzeczywistości. Melosik i Szkudlarek piszą o muzeum jako uosobieniu "nowoczesnych aspiracji w sferze panowania nad światem", o tendencjach do kontrolowania znaczeń oraz praktykowania egzekucji władzy nad czasem i przestrzenią ${ }^{24}$. Natomiast Bennett dodaje, iż zgodnie z nową polityką kulturalną rządów poszczególne artefakty wprowadzane na wystawy i do kolekcji muzealnych wspomagają rozwój metod przekształcania i wpływania przez rząd na nowe formy zachowań społecznych ${ }^{25}$, w tym z pewnością na postrzeganie i formowanie zbiorowej tożsamości kulturowej.

Dla dyskusji o muzealizacji pamięci w ramach działalności publicznych instytucji kultury, pozostających w bliskiej relacji wobec lokalnej polityki kulturalnej, źródłem będą przede wszystkim Strategie rozwoju Gdańska z lat 1998, 2004 i 2014. Dostarczają one informacji na temat rozwoju priorytetów polityki kulturalnej miasta, które to z kolei pozwalają na zaobserwowanie zmian w optyce tożsamościowej i pamięciowej Gdańska. W dokumencie z 1998 r. kulturę pojmowano jako dziedzictwo historyczne decydujące o tożsamości miasta, co przejawiało się dominującą troską o odbudowę i ochronę zabytków. To podczas tworzenia pierwszej strategii zapadały decyzje o dokończeniu odbudowy Śródmieścia, zagospodarowaniu Wyspy Spichrzów jako wyspy tradycji morskich i portowych, zaadaptowaniu m.in. kościoła św. Jana czy Wielkiej Zbrojowni na cele kulturalne, przywróceniu tradycji dzwonów, kurantów i organów

22 Poszerzenie pola kultury. Diagnoza potencjału sektora kultury w Gdańsku, red. Sławomir Czarnecki, Maciej Dzierżanowski, Martyna Grabowska, Jakub Knera, Lesław Michałowski, Cezary Obracht-Prondzyński, Krzysztof Stachura, Stanisław Szultka, Piotr Zbieranek, Gdańsk 2012, s. 37.

${ }_{23}$ Zbyszko Melosik, Tomasz Szkudlarek, Kultura, tożsamość i edukacja. Migotanie znaczeń, Kraków 2009, s. 30.

24 Ibidem, s. 27.

25 Tony Bennett, The Birth of the Museum. History, theory, politics, London-New York 1995, s. 6. 
Marta $\quad \mathrm{w}$ formie muzealnej z lokalizacją w kościele św. Katarzyny czy o rozbudowie Wróblewska Muzeum Archeologicznego o oddział prezentujący dzieje Gdańska jako miasta hanzeatyckiego ${ }^{26}$.

Druga strategia opublikowana w 2004 r., a więc zbieżna z wejściem Polski do Unii Europejskiej, nawiązuje już otwarcie do idei unijnych, zmierzających do ochrony i promocji tzw. tożsamości lokalnej, zwłaszcza poprzez koncentrowanie się na lokalnych inicjatywach kulturalnych. To także kolejne próby definiowania genius loci równoznacznego z tożsamością miejsca, poprzez podkreślanie idei wolności i otwartości jako jego nieodłącznych składowych, a także dbałości o dziedzictwo zarówno materialne, jak i duchowe ${ }^{27}$. Wydaje się, że to właśnie w tym momencie nastąpił pewien przełom w myśleniu i definiowaniu kulturowej tożsamości lokalnej. Zaczęto mówić o umacnianiu wspólnoty i tożsamości kulturowej gdańszczan, a jednym z narzędzi do osiągnięcia tego celu miała być integracja poprzez kulturę. Stąd obszernie planowane inwestycje w historyczne, materialne dziedzictwo Gdańska, troska o zabytkowe obiekty, które stanowią zabudowę Starego i Głównego Miasta. To także rozbudowa istniejących już w ramach historycznej zabudowy Gdańska instytucji (np. Muzeum Bursztynu czy Muzeum Morskiego) bądź powoływanie i budowa zupełnie nowych instytucji legitymizujących to młodsze oblicze lokalnej pamięci i tożsamości kulturowej (mowa tutaj m.in. o Europejskim Centrum Solidarności, Gdańskim Teatrze Szekspirowskim oraz Muzeum II Wojny Światowej).

Analiza Strategii rozwoju Gdańska z 2014 r. pozwala zrozumieć pewne tendencje coraz zachodzące w konsekwentnym profilowaniu lokalnych instytucji kultury ${ }^{28}$. Zapoczątkowana w strategii z $2004 \mathrm{r}^{29}$ europeizacja myślenia o mieście nabiera konkretniejszych kształtów. Mówi się o kulturze miejskiej i kulturze czasu wolnego, a także o niezmiennie istotnej roli kultury w procesie budowania tożsamości - i to zarówno miejskiej, jak i tej bardziej lokalnej - dzielnicowej. Zaczyna się podkreślać istotę kształtowania kompetencji kulturowych mieszkańców, ich kreatywności i partycypacji w rozwoju miasta - również tym kulturalnym. Odchodzi się zatem od głównej narracji związanej z pamięcią kulturową, zogniskowanej wokół historycznego centrum miasta. Do głosu coraz bardziej dochodzą lokalne historie indywidualnych mieszkańców, którzy zaczynają kreować i utrwalać własną pamięć związaną z małymi ojczyznami dzielnicowymi.

Ciekawą ilustracją tego długoletniego procesu redefiniowania pamięci kulturowej w związku z profilowaniem lokalnych instytucji kultury jest chociażby

\footnotetext{
26 Strategia rozwoju miasta Gdańska do roku 2010, przyjęta uchwałą Rady Miasta Gdańska, nr LXII/868/98 z dnia 17 czerwca 1998 r.

27 Strategia rozwoju miasta Gdańska do roku 2015, przyjęta uchwałą Rady Miasta Gdańska, nr XXXIII/1011/04 z dnia 22 grudnia $2004 \mathrm{r}$.

28 Gdańsk 2030 Plus. Strategia rozwoju miasta, przyjęta uchwałą Rady Miasta Gdańska nr LVII/1327/14 z dnia 25 września 2014 r.

29 Wspieranej specjalnym programem operacyjnym, stworzonym na potrzeby rewaluacji niezbędnej w okresie ubiegania się o tytuł Europejskiej Stolicy Kultury 2016.
} 
zestawienie pierwszej i ostatniej instytucji z Rejestru instytucji kultury prowadzonego przez miasto Gdańsk, których rejestrację dzieli dziewiętnaście lat. Listę otwiera powołany w $1981 \mathrm{r}$. (a wpisany do rejestru pod numerem instytucje kultury... 1 w 1992 r.) Zespół Muzyki Dawnej Cappella Gedanensis, przywołujący tradycje Kapeli Rajców Miejskich i opracowujący dzieła kompozytorów muzyki gdańskiej z XVII-XVIII w. ${ }^{30}$ Na końcu widnieje zaś Instytut Kultury Miejskiej, wpisany do rejestru w 2011 r. jako „otwarta instytucja kultury, do której można regularnie przychodzić" ${ }^{31}$, koncentrująca swoje działania wokół przestrzeni miejskiej, aktywizująca mieszkańców poszczególnych dzielnic i monitorująca stan rozwoju kultury w mieście. Ta klamra dobrze ilustruje rozwój polityki kulturalnej Gdańska na przestrzeni ostatnich dekad, przenoszenie akcentów lokalnej pamięci i ewolucję tożsamości kulturowej współczesnych gdańszczan.

Kolejnym źródłem informacji o procesach zachodzących w kształtowaniu pamięci kulturowej mieszkańców Gdańska będą badania społeczne i opracowania merytoryczne powstające w dużej mierze na zlecenie władz lokalnych. Analizują one i utrwalają procesy kulturowe, jakie w toku wdrażania kolejnych miejskich dokumentów strategicznych zachodzą wewnątrz lokalnej społeczności. Takie badania socjologiczne przeprowadzane są dość regularnie przez naukowców związanych z Uniwersytetem Gdańskim i Politechniką Gdańską. Towarzyszą one zazwyczaj istotnym jubileuszom miejskim, takim jak obchody tysiąclecia miasta, jubileusz dwudziestolecia samorządności czy organizowane co cztery lata światowe zjazdy gdańszczan ${ }^{32}$. Wyniki badań pozwoliły wyodrębnić zjawiska kulturowe zachodzące w świadomości gdańszczan. Pozostają one w dość bliskim związku z kierunkami rozwoju polityki kulturalnej miasta, utrwalając pewne toposy w lokalnym dyskursie dotyczącym pamięci i tożsamości kulturowej. Na pytanie: „Co wyróżnia Gdańsk na tle innych miast?”, postawione w badaniach opublikowanych przez Radosława Kryszka i Jarosława Załęckiego w przededniu obchodów tysiąclecia Gdańska, pada odpowiedź: starogdańska architektura, zabytki, wpływy różnych kultur. Wśród symboli Gdańska wymieniane są: kościół Mariacki, Żuraw, Fontanna Neptuna, Ratusz Głównomiejski, Trakt Królewski, Plac Solidarności wraz z Pomnikiem Poległych Stoczniowców, Dwór Artusa, Westerplatte, katedra Oliwska oraz ulica Mariacka ${ }^{33}$. Powyższe dane potwierdza także analiza Marka Szczepańskiego, z której wynika, że to „Starówka lub poszczególne jej obiekty” najbardziej kojarzą się z Gdańskiem i stanowią jego najistotniejsze osobliwości. Główne Miasto

http://development.cappellagedanensis.pl/ [dostęp: 18.07.2018].

31 http://ikm.gda.pl/idea/ [dostęp: 18.07.2018].

32 Por. analizę Marty Karkowskiej dotyczącą rozwijania i kultywowania zbiorowej pamięci kulturowej mieszkańców Olsztyna, przedstawioną na przykładzie obchodów rocznic inkorporacji Warmii do Polski (1454 r.) i II pokoju toruńskiego (1466 r.) w latach 1954 i 2004 oraz 1966 i 2006 w związku jubileuszami i obchodami rocznicowymi, zob. Karkowska, Pamięć kulturowa..., s. 86.

33 Radosław Kryszk, Jarosław Załęcki, Świadomość historyczna i tożsamość gdańszczan, „Rocznik Gdański” 1996, t. 56, z. 2, s. 82 i 87. 
Marta $\mathrm{z}$ jego zabytkową zabudową jest postrzegane przez respondentów badań jako Wróblewska miejsce święte, najściślej związane z poczuciem dumy miejscowej, które pełni funkcję symbolicznego, charakterystycznego obszaru na mapie miasta, z najważniejszymi punktami zaświadczającymi o historycznym i kulturowym dziedzictwie Gdańska ${ }^{34}$. Należy podkreślić, że wiele spośród zabytkowych obiektów czy też symbolicznych dla miasta miejsc wymienianych przez badanych gdańszczan zostało poddanych muzealizacji.

Oczywistą ilustrację powyższego stanowią choćby siedziby kluczowych gdańskich jednostek muzealnych (tych historycznych i tych nowoczesnych). Są nimi z pewnością Ratusz Głównomiejski wraz z Dworem Artusa oraz Domem Uphagena i Katownią, zlokalizowane przy Trakcie Królewskim i stanowiące filie Muzeum Historycznego Miasta Gdańska, które w końcu 2017 r. zmieniło nazwę na Muzeum Gdańska. Ekspozycje tam prezentowane w dużej mierze traktują przedmioty i przestrzenie muzealne jako relikty przeszłości, unaoczniające wiedzę o minionych czasach, co jest zresztą charakterystyczne i naturalne dla muzeów historycznych ${ }^{35}$. Często funkcjonują one na zasadzie „wehikułów czasu"36 rekonstruujących rzeczywistość, w której zostały utworzone jako obiekty użytkowe. Ekspozycja w Domu Uphagena to przede wszystkim wnętrza domu mieszkalnego zamożnego rodu gdańskich patrycjuszy, a więc historia mieszczaństwa gdańskiego realizującego świadomą kulturotwórczą misję utworzenia i zachowania świadectwa kultury zarówno materialnej, jak i intelektualnej swojej epoki ${ }^{37}$. Ratusz Głównego Miasta wraz z Dworem Artusa mają ilustrować z kolei wielowiekowe tradycje Gdańska jako miasta samorządnego, niezależnego, zamożnego, o silnym poczuciu własnej wartości. W wieży Katowni, obok aranżacji cel więziennych nawiązujących do historii miejsca, urządzono siedzibę Muzeum Bursztynu - jednego z naczelnych symboli miasta. Ekspozycja bursztynu prezentuje zarówno tradycyjne techniki jego obróbki, jak i naturalne oraz artystyczne aspekty jego wykorzystania. Przede wszystkim jednak jest odniesieniem do okresu, w którym Gdańsk pełnił rolę jednego z najważniejszych ośrodków rzemiosła bursztynniczego. Prezentacja tradycji związanych z bursztynem znalazła miejsce także w Domu Przyrodników, oddziale Muzeum Archeologicznego w Gdańsku (ekspozycje: „Bursztyn w kulturze” i „Bursztyn w przyrodzie"), obok narracji dotyczącej pradziejów Gdańska. Natomiast Żuraw, będący jednym z oddziałów Narodowego Muzeum Morskiego, sam w sobie

${ }_{34}$ Marek S. Szczepański, Podróże po mniejszym niebie. Ojczyzna prywatna w oglądzie socjologicznym [w:] Tożsamość miejsca i ludzi. Gdańszczanie i ich miasto w perspektywie historyczno-socjologicznej, red. Małgorzata Dymnicka, Zbigniew Opacki, Gdańsk 2003, s. 142-143.

35 Michał Woźniak, Ochrona dziedzictwa kulturowego, a muzea Pomorza Nadwiślańskiego [w:] Muzea a dziedzictwo kulturowe Pomorza. Materiały konferencji jubileuszowej, Wejherowo, 24 X 1998, red. Józef Borzyszkowski, Wejherowo-Gdańsk 2000, s. 16.

36 Porównanie to wprowadził w 1988 r. Peter Lumley, por. Sharon Macdonald, Theorizing museums: an introduction [w:] Theorizing museums. Representing identity and diversity in a changing world, red. Sharon Macdonald, Gordon Fyfe, Oxford 1996, s. 9.

37 Por. Woźniak, Ochrona dziedzictwa..., s. 18. 
stanowiący wizytówkę wizualną miasta, jest niezaprzeczalnym ucieleśnieniem morskiej i portowej tradycji Gdańska, z którą sami mieszkańcy silnie się utożsamiają, co wynika z przytoczonych powyżej badań ${ }^{38}$.

Jak zostało to zaznaczone na początku, termin odnoszący się do miejsc pamięci obejmuje nie tylko historyczne budowle, lecz także postacie istotne dla budowania pamięci kulturowej miasta bądź wydarzenia czy zjawiska ją wzmacniające. Za Assmannem nazwalibyśmy je Erinnerungsfiguren - figurami pamięci bądź ich strażnikami. Główną ich funkcją jest zapewnienie ciągłości pewnych związanych z nimi znaczeń, na których budowana jest pamięć zbiorowa ${ }^{39}$. Ich przenikanie do świadomości społecznej jest ściśle związane z procesem edukacji społeczeństwa, a także wypracowywaniem symboli, z którymi dana grupa mogłaby się utożsamić i włączyć je do systemu własnych idei. Nieprzypadkowa jest tu także rola władz, którym Assmann przypisuje moc decyzyjną w wyznaczaniu „wyspecjalizowanych przedstawicieli strażników pamięci do przedstawiania akceptowanej przez nie wizji historii miasta, czyniąc ich odpowiedzialnymi za przygotowanie i przebieg ceremonii upamiętniania" 40 .

Przypadek Gdańskiego Teatru Szekspirowskiego pokazuje, jak podczas wdrażania strategii kulturalnej miasta kreuje się takie figury pamięci, które z czasem, za pośrednictwem legitymizujących działań instytucji, zaczynają być integralną częścią pamięci kulturowej miasta. Żadne z cytowanych powyżej badań socjologicznych nie przywoływały Williama Szekspira i tradycji teatru elżbietańskiego w Gdańsku. Mimo to działalność Gdańskiego Teatru Szekspirowskiego z pewnością zapoczątkowała, a następnie skutecznie umocniła w świadomości gdańszczan ten element pamięci kulturowej z pogranicza dziedzictwa materialnego i niematerialnego (nowoczesna siedziba teatru nawiązuje do tradycji budowlanych siedemnastowiecznej szkoły fechtunku, w której miały odbywać się spektakle wędrownych trup teatralnych m.in. z Anglii).

Powyższy fenomen związany jest poniekąd $z$ konstruowaniem współczesnego panteonu ważnych i zasłużonych dla Gdańska postaci, które zostają patronami poszczególnych instytucji kultury. Takim przykładem jest powstała w $2009 \mathrm{r}$. Gdańska Galeria Güntera Grassa (jako jeden z trzech oddziałów Gdańskiej Galerii Miejskiej), której jednym z głównych celów statutowych jest propagowanie twórczości urodzonego w Gdańsku noblisty. Działania te odbywają się wielotorowo, koncentrując się przede wszystkim wokół dialogu artystów współczesnych z kolekcją dzieł rzeźbiarskich, rysunkowych i graficznych, podarowanych miastu przez autora lub zakupionych przez miasto w ramach rozbudowywania galerii.

We wspomnianym przeze mnie panteonie autorzy Strategii rozwoju miasta z 2004 r. umieścili także m.in. Jana Heweliusza, Daniela Chodowieckiego, Artura

Kryszk, Załęcki, Świadomość historyczna..., s. 87.

9 Karkowska, Pamięć kulturowa..., s. 165.

40 Ibidem, s. 210-224. 
Marta Schopenhauera czy Lecha Wałęsę. Ten ostatni zajmuje ważne miejsce w narracji Wróblewska Europejskiego Centrum Solidarności. Przez pewien czas prowadzono próby wpisania w mapę pamięci kulturowej miasta warsztatu Wałęsy, miejsca nadal znajdującego się na terenie byłej Stoczni Gdańskiej. Pomysł (sprzed kilku lat) uczynienia z warsztatu Wałęsy kolejnego miejsca pamięci, będący oddolną inicjatywą współprowadzącego wówczas Fundację Wyspa Progress Grzegorza Klamana, nie został jednak podjęty później przez miasto i nie jest kontynuowany. Z kolei próby wzmocnienia postaci Heweliusza w pamięci kulturowej gdańszczan zmierzają w kierunku nadania mu miana patrona nauki. Osoba astronoma została powiązana z Muzeum Zegarów Wieżowych, znajdującym się w wieży kościoła św. Katarzyny. Eksponowanej tam przekrojowej kolekcji zegarów towarzyszy niewielka prezentacja planszowa dotycząca życia oraz osiągnięć Heweliusza, do których zalicza się m.in. skonstruowanie zegara wahadłowego. Placówka jest częścią Muzeum Gdańska i od niedawna funkcjonuje pod nazwą Muzeum Nauki Gdańskiej, co zapewne zmierza ku bliższemu jej powiązaniu w przyszłości z wizerunkiem Heweliusza promowanym przez miasto.

Ciekawe perspektywy ma osadzanie w lokalnej pamięci i tożsamości kulturowej postaci Chodowieckiego. O ile Heweliusz, Wałęsa czy Grass pojawiali się wśród wybitnych gdańszczan wymienianych przez respondentów w badaniach przytaczanych przez Kryszka i Załęckiego, o tyle Chodowieckiemu (i Szekspirowi) nie poświęcano dotąd uwagi. Biografię i dokonania urodzonego w Gdańsku osiemnastowiecznego grafika przypomniał natomiast sam Grass, który z postacią Chodowieckiego bardzo się identyfikował ze względu na wątki migracyjne, artystyczne, ale także wielokulturowe, obecne w biografiach obydwu z nich. Chodowiecki ze swoim życiorysem artystycznym oraz pochodzeniem polsko-szwajcarsko-hugenockim na tyle silnie wpisuje się w wizję wielokulturowości Gdańska, stanowiącą silny element, obecnej tożsamościowej polityki miasta, że zdecydowano się poświęcić mu osobną instytucję. W ostatecznym kształcie będzie ona projektem jednoczącym dwie marki wybitnych gdańszczan w ramach jednego przedsięwzięcia funkcjonującego pod nazwą Dom Daniela Chodowieckiego i Güntera Grassa ${ }^{41}$. Podczas gdy jej program ideowy jest nadal kwestią dyskusji, bezdyskusyjna jest lokalizacja nowej placówki, na którą przeznaczono zabytkowy Dom Dobroczynności i Sierot przy ulicy Sierocej. Budynek nie uległ zniszczeniom podczas drugiej wojny światowej, ale jest obecnie w złym stanie technicznym i zostanie poddany renowacji - zgodnie z dobrą tradycją muzealizacji historii miasta poprzez przekazywanie zabytkowych budynków na działalność instytucji kultury ${ }^{42}$. Na potrzeby przyszłej działalności i prezentowanej tam ekspozycji gromadzona jest kolekcja dzieł artystycznych Chodowieckiego. Lokalizacja Domu Chodowieckiego i Grassa tuż naprzeciwko Muzeum Poczty

\footnotetext{
${ }^{41}$ Dom Chodowieckiego i Grassa stanie się czwartym oddziałem Gdańskiej Galerii Miejskiej w miejsce funkcjonującej od 2009 r. Gdańskiej Galerii Güntera Grassa.

42 Por. Friedrich, Polskość?..., s. 170-171.
} 
Polskiej, a także w niedalekiej odległości od Muzeum II Wojny Światowej oraz znajdujących się na terenach postoczniowych Europejskiego Centrum Solidarności i powstającego Muzeum Sztuki Współczesnej (jako oddziału Muzeum Narodowego w Gdańsku) ma dodatkowo szansę wpisać się w bardzo ciekawy i nowy kulturalny kwartał tej - dotąd niezbyt ożywionej - części miasta.

Trzecim obszarem analizowanym w kontekście mówienia o miejscach pamięci, rozumianych w szerokim pojęciu Nory, są istotne dla danego miasta lub jego społeczności wydarzenia. Redaktor jednego z głównych opracowań dotyczących tematu tożsamości gdańskiej, Basil Kerski, pisze tak: „Gdańsk jest europejskim miejscem pamięci: tu rozpoczęła się druga wojna światowa i tutaj narodziła się Solidarność, jeden z największych i najbardziej skutecznych pokojowych ruchów XX w." ${ }^{43}$ To, że teza ta stanowi jeden z fundamentów lokalnej tożsamości i pamięci, potwierdzają cytowane już badania Kryszka i Załęckiego ${ }^{44}$. Wynika z nich, że trzema najważniejszymi wydarzeniami w historii Gdańska w opinii jego mieszkańców są: porozumienia sierpniowe z 1980 r., początek drugiej wojny światowej oraz przyłączenie Gdańska do Polski w 1945 r. Potwierdza to poniekąd uwagi, poczynione m.in. przez Loewa, o swoistej amnezji współczesnych gdańszczan wobec historii miasta sprzed drugiej wojny światowej ${ }^{45}$.

Dopiero stosunkowo niedawno zaczęly postawać instytucje bądź ekspozycje rezonujące z tymi elementami pamięci kulturowej gdańszczan. Otwarte w $2014 \mathrm{r}$. Europejskie Centrum Solidarności oraz zainaugurowane w 2017 r. Muzeum II Wojny Światowej reprezentują nową formę upamiętniania poprzez wznoszenie obiektów architektonicznych stanowiących rodzaj pomników samych w sobie. Zlokalizowane przy Placu Solidarności ECS jest współczesnym pomnikiem tej części gdańskiej historii, z którą jego obywatele najchętniej się utożsamiają. Dla prezentowanej tam wystawy stałej główną osią jest „Sierpień 1980 r.” i powstanie Solidarności, a jego architektura nawiązuje do bezpośredniego otoczenia stoczniowego poprzez użycie okładziny ze stali kortenowskiej przypominającej zardzewiały kadłub statku. Muzeum II Wojny Światowej mieści się w budynku przypominającym piramidalny klin wbity w miejsce najstarszego historycznie obszaru osadniczego i miejskiego Gdańska ${ }^{46}$. Ta nowoczesna konstrukcja, stanowiąca charakterystyczną dominantę krajobrazu miasta, stała się w szybkim tempie jedną z najbardziej rozpoznawalnych budowli, wyróżniających się wśród historyzującej i dość homogenicznej architektury gdańskiego Sródmieścia. Pierwotna ekspozycja oraz narracja Muzeum II Wojny Światowej zostały sformatowane także pod kątem spełniania zbiorowych potrzeb nowoczesnych wspólnot obywatelskich i polegają w dużym stopniu na bezpośrednim angażowaniu publiczności. Czytelne jest to przede wszystkim w filozofii budowania kolekcji i jej prezentowania, którą Paweł Machcewicz - pierwszy dyrektor

43 Basil Kerski, Gdańskie tożsamości. Wstęp do antologii [w:] Gdańskie tożsamości..., s. 7.

44 Por. Kryszk, Załęcki, Świadomość historyczna..., s. 77-91.

45 Por. Loew, Historia szuka pamięci..., s. 143-148.

46 Peter Oliver Loew, Gdańsk. Biografia miasta, przeł. Justyna Górna, Gdańsk, 2013, s. 39. 
Marta muzeum i współtwórca koncepcji wystawy stałej - charakteryzuje w następujący Wróblewska sposób: „Muzeum jest miejscem, które za pomocą prezentowanych eksponatów chce podkreślić znaczenie autentycznych przedmiotów w opowiadaniu o historii [...]" - należy dodać - historii osobistych, indywidualnych i przez to niepowtarzalnych ${ }^{47}$. Muzealizacja życia codziennego, często wraz z jego przeciętnością i przyziemnością, sprzyjająca budowaniu więzi z odbiorcą, który jest w sposób otwarty zapraszany do złożenia osobistej kontrybucji w postaci pamiątek prywatnych w darze do kolekcji muzeum, aby przez to współtworzyć i współstanowić o jego kształcie, jest - jak do tej pory - fenomenem w skali Gdańska.

Rodzajem istotnego uzupełnienia do (około)wojennej pamięci kulturowej współczesnych gdańszczan jest ekspozycja prezentowana w Muzeum Poczty Polskiej. Ten oddział Muzeum Gdańska, mieszczący się w odbudowanej po częściowych zniszczeniach pierwotnej siedzibie Poczty Polskiej, nawiązuje nie tylko do samej obrony instytucji we wrześniu 1939 r., lecz także do międzywojennej historii Wolnego Miasta Gdańska, stanowiącej szerokie tło społeczne, polityczne i kulturowe dla narracji głównej ekspozycji. W misję Muzeum Poczty Polskiej, jak czytamy w przewodniku muzealnym, wpisane jest „kultywowanie pamięci o obronie i obrońcach, a także o ich rodzinach i Polakach żyjących w Wolnym Mieście Gdańsku (1920-1939). Ekspozycja jest narracją nie tylko o historii, ale także o pamięci, a w tle pojawiają się te same, co w przypadku wojny, pytania o sens, motywację, granice poświęcenia czy patriotyzm - w kontekście przeszłości i teraźniejszości" ${ }^{48}$. Wystawa stała budowana jest w dużej mierze w oparciu o tzw. historię mówioną. Składają się na nią świadectwa zebrane wśród żyjących świadków historii - zazwyczaj członków rodzin poległych pocztowców, którzy w okresie Wolnego Miasta Gdańska kształtowali obraz społeczny, polityczny i kulturalny mniejszości polskiej. Ich osobisty punkt widzenia znacząco pozycjonuje perspektywę prowadzonej narracji. Niezwykle istotnym elementem utrwalania pamięci o obrońcach Poczty Polskiej jest również praca na muzealiach będących osobistymi pamiątkami po zamordowanych.

Mówiąc o instytucjach kultury jako miejscach pamięci, warto poruszyć także kwestie związane z istotą i profilem samych procesów muzealizacji. Szereg teorii na temat zjawiska muzealizacji jako sposobu formowania dziedzictwa, pamięci i tożsamości przytacza Sharon Macdonald w opracowaniu Memorylands. Heritage and Identity in Europe Today. Wśród cytowanych przez badaczkę opracowań pojawiają się definicje muzealizowania jako kompensacji (Joachim Ritter) erozji tradycji poprzez jej instytucjonalizację i włączanie w obieg pamięci kulturowej ${ }^{49}$. Jednocześnie Macdonald przywołuje innego niemieckiego badacza - Hermanna

47 Muzeum II wojny światowej: katalog wystawy głównej, oprac. Rafał Wnuk, Paweł Machcewicz, Oliwia Gałka-Olejko, Łukasz Jasiński, Jan Daniluk, Gdańsk 2016, s. 12.

48 Janusz Trupinda, Muzeum Poczty Polskiej w Gdańsku. Przewodnik, Muzeum Historyczne Miasta Gdańska, Gdańsk 2017.

49 Sharon Macdonald, Memorylands. Heritage and Identity in Europe Today, London-New York 2013, s. 138. 
Lübbe - który obserwuje wzrost tendencji związanej z muzealizacją, przypisując ją zmianie w pojmowaniu pojęcia czasowości, w dużej mierze utożsamianej z dominacją nowych technologii i zwiększeniem szybkości życia (Macdonald pisze o tempie, z jakim teraźniejsze wydarzenia przechodzą do sfery przeszłości). $\mathrm{W}$ tym sensie muzealizacja stanowi narzędzie do zakotwiczenia się w czasie w obliczu poczucia destabilizacji wobec jego upływu ${ }^{50}$. Z drugiej strony - według cytowanego przez Macdonald Andreasa Huyssena - muzea można pojmować jako rodzaj pól eksperymentalnych, gdzie testowane są rozmaite podejścia do pojęcia subiektywności, tożsamości i zmienności ${ }^{51}$. O swoistej wybiórczości w ustanawianiu nowych granic i kanonów kulturalnych mówił także Jean Baudrillard, określając ją jako zjawisko symptomatyczne dla kultury ponowoczesnej, którą z tego powodu nazywał „mozaikową”, grającą kawałkami rekonstruowanej przeszłości, na której fundamentach buduje się własne teraźniejsze wersje pamięci i tożsamości ${ }^{52}$. Ta nostalgia wobec przeszłości, stanowiącej silny fundament lokalnego dziedzictwa, a także potrzeba dopasowania jej do własnej teraźniejszości związanej z redefiniowaniem pojęcia tożsamości i pamięci kulturowej wydają się Gdańskowi bardzo bliskie.

Jeśli zatem przyjmiemy, że instytucje kultury, w tym przede wszystkim muzea, istnieją po to, aby nadawać ramy lokalnej pamięci i tożsamości, snując pewną określoną historię powstającą $\mathrm{w}$ wyniku procesu muzealizacji nie tylko wybranych artefaktów, lecz także miejsc, wydarzeń czy postaci, to musimy zadać pytanie: jaki obraz pamięci i za pomocą jakich narzędzi jest konstruowany w Gdańsku. Większość gdańskich muzeów niejednokrotnie pełni jednocześnie funkcję pomników architektonicznych, świadków historii prezentujących pamięć o miejscach często już nieistniejących w oryginalnej postaci (por. pamięć przez rekonstrukcję). Bardzo dobrymi przykładami tej formuły są wszystkie oddziały Muzeum (do niedawna Historycznego Miasta) Gdańska, z tak kluczowymi dla pejzażu pamięciowego Gdańska obiektami, jak zrekonstruowany Dwór Artusa i Ratusz Głównego Miasta, których funkcja świadków historii, naznaczona opisaną na początku palimpsestowością pamięci gdańskiej, powielona jest w narracjach ukazanych w ich wnętrzach.

Dwór Artusa, jak czytamy w informacji towarzyszącej ekspozycji stałej, jest od XIV w. „nieodłącznym elementem krajobrazu miasta”, stanowiącym symbol zarówno tradycji mieszczańsko-kupieckich Gdańska, jak i idei rycerskich wpisujących miasto w szerszy kontekst średniowiecznej kultury europejskiej. Będąc „najbardziej elitarną piwiarnią Europy”, gdzie reprezentanci wyższych warstw społecznych, na czele z królem, spędzali czas „przy kuflu piwa i rozmowie”, jest jednocześnie „salonem miasta” podejmującym dostojnych

Ibidem.

$51 \quad$ Ibidem, s. 140.

52 Gra resztkami (wywiad z Jeanem Baudrillardem przeprowadzony przez Salvatore Mele i Marka Titmarsha) [w:] Postmodernizm a filozofia, red. Stanisław Czerniak, Andrzej Szahaj, Warszawa 1996, s. 205 i 226. 
Marta Wróblewska

gości. Wystrój Dworu Artusa nie uwzględnia jednak wspominanego kufla gdańskiego ${ }^{53}$. Ukierunkowany jest raczej na podkreślanie tradycji morskich (poprzez ekspozycję modeli statków pierwotnie pochodzących z Muzeum Morskiego, które przeprowadzało tam swoje pierwsze działania wystawiennicze w latach sześćdziesiątych XX w.). Silnie obecne są także motywy związane $\mathrm{z}$ łowiectwem (głównie mitologiczne, np. wizerunki Diany) i tradycją rycerską, które odnoszą się do etosu średniowiecznego (ukazane sceny polowań, wizerunki św. Jerzego, rzeźby wojowników). Tendencje moralizatorskie wybrzmiewają w scenach biblijnych przedstawiających m.in. wizerunki świętych, stanowiących exempla dla bywalców Dworu. Istotną częścią wystroju jest również to, czego nie ma. Poszczególne części Dworu Artusa opatrzone są informacjami dotyczącymi braków w oryginalnym wystroju wnętrza, powstałych w wyniku strat wojennych. Brakuje tarcz herbowych, obrazów olejnych czy też grup malarsko-rzeźbiarskich. Próby rekonstrukcji utraconych dzieł z wykorzystaniem nowych (jak na ówczesne czasy) możliwości technologicznych podjęto w latach 1999-2000, zastępując m.in. oryginalny obraz Sądu Ostatecznego Antona Möllera rekonstrukcją fotograficzno-cyfrową wykonaną przez Krzysztofa Izdebskiego. Tego rodzaju zabiegi kompensacyjne nie tylko przywołują obraz tego, co utracone, lecz także stają się narzędziami do praktykowania trudnej pamięci dotyczącej strat będących istotną częścią dwudziestowiecznej historii miasta.

Ratusz Głównomiejski stanowi przede wszystkim obraz historii politycznej miasta. Jej meandry dobrze ilustruje przykład wystroju Wielkiej Sali Wety. Prezentowana tam galeria dziewięciu królów polskich została odtworzona w $1998 \mathrm{r}$. przy wsparciu finansowym Fundacji Rafinerii Gdańskiej SA dla uczczenia obchodów milenijnych miasta i nawiązuje do historycznego wystroju wnętrza sprzed $1793 \mathrm{r}$. (czyli sprzed ingerencji władz pruskich, które dzieła z sali usunęły $)^{54}$. Owe rekonstrukcje historyczne współegzystują od dwudziestu lat $z$ historyzującym wystrojem sali, wykonanym przez artystów reprezentujących optykę obowiązującą w Gdańsku bezpośrednio w latach powojennych. Wśród nich charakterystyczny jest gobelin z 1975 r. autorstwa Hanny Żuławskiej, który zwieńczono napisem: „Gdańsk, prastary słowiański gród nadbałtycki, od zarania swych dziejów związany z Polską, rósł w potęgę i bogactwo, pod berłem królów polskich dla dobra swych obywateli i chwały Rzeczypospolitej Polskiej stał wiernie u jej morskich granic". Jest on wszakże świadkiem pamięci reprezentującej kierunki polityki historycznej i tożsamościowej, promowanej przed 1989 r., będącej jednocześnie częścią mitu „polskości” Gdańska, o którym pisał Loew.

53 Tego typu obiekty są częścią ekspozycji sąsiedniego Ratusza Głównego Miasta czy też galerii złotnictwa Muzeum Narodowego w Gdańsku, gdzie pełnią rolę wyabstrahowanych z pierwotnego kontekstu artefaktów muzealnych.

${ }_{54}$ O utrwalaniu tradycji polskiej w Gdańsku po drugiej wojnie światowej w związku z oswajaniem miejsca poprzez przywoływanie symboli, takich jak m.in. królowie polscy, zob. Jacek Friedrich Odbudowa Głównego Miasta w Gdańsku w latach 1945-1960, Gdańsk 2015, s. 65. 
W ciekawej sytuacji znajdują się te muzea, które prezentują wystawy $\mathrm{w}$ oddziałach zainaugurowanych bądź zaaranżowanych z dużym odstępem czasowym. Mam tu na myśli przede wszystkim Narodowe Muzeum Morskie i Muzeum Archeologiczne. To pierwsze znajduje się w czterech charakterystycznych obiektach zlokalizowanych w samym centrum Gdańska - spichlerzach na Ołowiance, Żurawiu, „Sołdku” oraz Ośrodku Kultury Morskiej. Ten ostatni - najmłodszy z oddziałów - otwarty w 2012 r., oddzielony od spichlerzy kanałem Motławy, dostarcza nowoczesnego komentarza do wielu prezentowanych na Ołowiance wątków i obiektów zabytkowych w formie interaktywnej i edukacyjnej prezentacji, skierowanej przede wszystkim do młodszych odbiorców. Ekspozycja została zaaranżowana w sposób aktualny, odnoszący się do bezpośrednich realiów dzisiejszego Gdańska jako miasta portowego. W ramach części wystawy zatytułowanej „Ludzie - statki - porty” prezentowane są informacje technologiczne dotyczące przemysłu portowego. Zastosowanie nowoczesnych narzędzi wyrazu w postaci filmów i nagrań dźwiękowych czy symulatorów np. pojazdu podwodnego, a także prowadzenie narracji w przystępny i atrakcyjny sposób sprzyja aktywizacji zwiedzających. Proces budowy terminala kontenerowego można odtworzyć samodzielnie na mniejszą skalę przy użyciu popularnych klocków Lego. Sporo miejsca poświęcono także flagowej dziedzinie, którą zajmuje się Narodowe Muzeum Morskie, tj. archeologii podwodnej, ilustrując procesy i mechanizmy z nią związane. Szczególna część prezentacji dotyczy ludzi stojących za przemysłem morskim, ich zadań i obowiązków związanych z codzienną pracą, ale także kultury spędzania czasu na morzu, zilustrowanej materiałami filmowymi, elementami sprzętu profesjonalnego oraz interaktywnymi zadaniami dla zwiedzających. Wystawa w spichlerzach pokazuje z kolei bardziej tradycyjne podejście do prezentacji zbiorów. Zaaranżowana chronologicznie, prowadzi widza przez historię żeglugi nad Bałtykiem, zaczynając od śledzenia początków aktywności morskiej Słowian na tym terenie, których znaczenie i obecność legitymizują popiersia pierwszych królów Polski - Mieszka I i Bolesława Chrobrego, wykonane przez gdańską artystkę współczesną - Krystynę Filipską-Frejer. Warto zauważyć, że wplatanie w wystawę historyczną wykonanych współcześnie prac artystów lokalnych jest $\mathrm{w}$ tym przypadku ewenementem w skali muzeów gdańskich. Oprócz wspomnianych popiersi królewskich na wystawie stałej w spichlerzach znajdziemy także m.in. obraz Wiesława Matuszka Gdańsk wczesnośredniowieczny, tkaninę Hanny Koralewicz Zagospodarowanie wybrzeży południowego Bałtyku czy też marynistyczne malarstwo Henryka Baranowskiego ukazujące zwycięskie bitwy na Zalewie Wiślanym. Szczególną uwagę zwraca ekspozycja zaaranżowana z obiektów pochodzących z wyłowionego "Miedziowca” z towarzyszącą jej informacją na temat rekompensacyjnej roli archeologii podwodnej w obliczu muzealnych strat powojennych i fundamentalnego znaczenia prac podwodnych w tworzeniu nowych polskich kolekcji nautologicznych. 
Marta Muzeum Archeologiczne w Gdańsku posiada pięć oddziałów, spośród Wróblewska których najbardziej prominentnym jest tzw. Dom Przyrodników, usytuowany przy ulicy Mariackiej znajdującej się w sercu ruchu turystycznego. Wystawę główną w tejże placówce rozpoczyna tablica chronologiczna pradziejów Pomorza Wschodniego, wykaligrafowana odręcznie na tekturze. Ta estetyka będzie konsekwentnie kontynuowana podczas całej prezentacji obiektów umieszczonych głównie w szklanych muzealnych gablotach i stanowiących przegląd kolejnych epok w dziejach regionu, ilustrowanych znaleziskami z przeprowadzonych lokalnie wykopalisk. Czynnik ludzki tej historii dominuje zwłaszcza w części ekspozycji zatytułowanej „Schorzenia ludności prahistorycznej na ziemiach polskich". Ilustrują ją przede wszystkim elementy szkieletów ludzkich, na czele z postacią trędowatego złożonego w szklanej gablocie opatrzonej następującym komentarzem: „Choroba ta jest jedną z najdłużej towarzyszących człowiekowi zakaźnych chorób skóry i nerwów. Wywołana jest przez prątki trądu (Mycobacterium leprae). Trąd został przywleczony do Polski przez Krzyżowców". Kościotrupy złożone w tym muzeum - parafrazując słowa Zygmunta Baumana - jednak nie wstają ${ }^{55}$. Inaczej sprawa się miała na ekspozycji ulokowanej w spichlerzu Błękitny Baranek po drugiej stronie Motławy (obecnie zamkniętym $\mathrm{z}$ powodu prowadzonego remontu), stanowiącej w dużej mierze edukacyjne i interaktywne uzupełnienie wystawy głównej (jak w przypadku Muzeum Morskiego). Tematem przewodnim tej wystawy była historia średniowiecznej Hanzy, wyłaniająca się z badań archeologicznych i antropologicznych przeprowadzonych w Gdańsku. Te ostatnie postawiły w centrum wystawy człowieka. To dawni gdańszczanie, z sylwetkami i rysami twarzy zrekonstruowanymi na podstawie badań szkieletów, byli głównymi bohaterami replik uliczek hanzeatyckich z ich odgłosami, zapachami i przedmiotami życia codziennego. Ten immersyjny zabieg przenoszący widza w czasie za sprawą trójwymiarowej wizualizacji, poparty doświadczeniami naukowymi zilustrowanymi także na wystawie w postaci filmów instruktażowych, wydawał się w momencie otwarcia spichlerza przełomem w wytyczaniu dróg nowej muzeologii historycznej w Gdańsku. Autorefleksja na temat własnej misji i działalności, angażująca widza interaktywny i ciekawy w sposób, z pewnością spełniła założenia scenariusza wystawy z 2008 r., zmierzające m.in. ku pomocy w zrozumieniu i docenieniu regionalnego dziedzictwa archeologicznego, przeprowadzeniu widza przez swoistą podróż w czasie z wykorzystaniem multimediów i rekonstrukcji, a także przedstawieniu archeologii jako dziedziny interdyscyplinarnej oraz prezentowaniu rezultatów tej ciekawej współpracy między naukami.

\footnotetext{
5 Cytat, odnoszący się do roli i kształtu nowoczesnego muzeum, brzmi następująco: „Przy takim usposobieniu odbiorców dzieła sztuki muzea pragnące uczestniczyć w estetycznym festynie i coś dla siebie uszczknąć z jego zdolności przykuwania uwagi widza, muszą wyzbyć się swego powinowactwa $\mathrm{z}$ cmentarzami i mauzoleami. Kościotrupy złożone w muzeach na przechowanie muszą wstawać [...]”, zob. Zygmunt Bauman, Nieco plynnych myśli o sztuce w plynie, przeł. Adriana Kunka [w:] idem, Między chwila a pięknem o sztuce w rozpędzonym świecie, Łódź 2010, s. 20.
} 
Powyższe przykłady ilustrują tendencję do wychodzenia kultury poza debaty akademickie. Elementy związane z pamięcią i tożsamością kulturową wchodzą do dyskusji o podłożu politycznym i społecznym, stając się narzędziem analizy wykorzystywanym w bardzo szeroko rozumianej humanistyce ${ }^{56}$. Instytucje kultury przestają być postrzegane wyłącznie jako świątynie poświęcone sztuce i wielkiej historii, do których dostęp mają jedynie elity intelektualne, lecz stopniowo otwierają się na indywidualnego obywatela, prezentując pamięć i dziedzictwo kulturowe także z jego perspektywy ${ }^{57}$.

Zjawisko to można zaobserwować na szeroką skalę we współczesnej Europie. Obecne zdarzenia i tendencje mające miejsce na polu polityki, socjologii i kultury popychają kolejne kraje wspólnoty do rewizji swoich polityk kulturalnych, a miasta - ku bliższemu przyglądaniu się strategiom działań swoich instytucji kultury, instytucje z kolei - do redefinicji misji oraz profilów działalności. Tendencje te dotyczą przede wszystkim narracji prezentowanych w ramach wystaw stałych oraz refleksji wobec gromadzonych kolekcji ${ }^{58}$. W toku tych dyskusji i przedsięwzięć związanych bezpośrednio z narracjami prezentowanymi w instytucjach kultury powracają wielokrotnie pytania o pamięć, kanon w sztuce oraz strategie budowania i pokazywania kolekcji z zachowaniem różnorodności perspektyw. Ten zwrot, zauważalny na coraz większą skalę, zwłaszcza w instytucjach niemieckich, jest $\mathrm{w}$ dużej mierze wynikiem toczących się debat na temat m.in. migracji w Europie i związanej z nimi potrzeby rewizji postrzegania nowej europejskiej tożsamości. Jest to dowód na to, jak bardzo procesy kulturowe i artystyczne są uwrażliwione na wpływ sytuacji politycznej i społecznej w poszczególnych państwach. Proces ten nie omija w istocie instytucji kultury jako jednostek finansowanych i organizowanych przez samorządy czy organy centralne. Trafnie opisują ten związek Assmannowie, ujmując władzę jako inicjatora i decydenta w procesie wskazywania,

6 Por. du Gay, Organizing Identity..., s. 151.

57 Por. Macdonald, Memorylands..., s. 144.

58 Bardzo ciekawe praktyki, ilustrujące powyższe obserwacje, mają miejsce w stolicy naszego najbliższego zachodniego sąsiada - Republiki Federalnej Niemiec - gdzie muzea regularnie budują aktualny program wystawienniczy w oparciu o krytyczną analizę swoich kolekcji. Oprócz niegasnącej dyskusji toczącej się wokół charakteru wystawy stałej w będącym na ukończeniu Humboldt Forum, którego otwarcie przewidziano na rok 2019, na szczególną uwagę zasługuje eksperyment wystawienniczy o symbolicznym tytule: „Unvergleichlich. Kunst aus Afrika im Bode-Museum” („Nieporównywalne. Sztuka z Afryki w Bode Museum”). Za pomocą dość zaskakujących zestawień arcydzieł rzeźbiarskich sztuki europejskiej i afrykańskiej Bode Museum inicjuje dyskusję na temat rewizji kanonu w sztuce, która pozostaje w bliskim związku z dyskursem dotyczącym rewizji pamięci kulturowej Europy (zwłaszcza Zachodniej). Znaczącą i niezwykle frapującą transformację przeszła także wystawa stała w Märkisches Museum. To berlińskie muzeum założone i wybudowane pod koniec XIX w. w wyniku obywatelskiej inicjatywy pasjonatów historii miasta, wprowadziło nowoczesne elementy i rozwiązania do prezentacji tradycyjnych artefaktów pochodzących z jego zbiorów. Dzięki temu bezpośrednio powiązało narrację historyczną z aktualnymi kwestiami społeczno-kulturowymi, jakimi są m.in. imigranci, lokalne tradycje dzielnicowe czy wielokulturowość, stanowiące istotny element współcześnie formatowanej pamięci kulturowej Berlina. 
Marta kontrolowania i nadzorowania nośników (czy to w postaci miejsc, osób, czy wydaWróblewska rzeń) pamięci kulturowej ${ }^{59}$.

Instytucje w Gdańsku, które zostały ustanowione stosunkowo niedawno, jak Europejskie Centrum Solidarności czy Muzeum II Wojny Światowej, od początku bardzo świadomie definiowały siebie zarówno w relacji do coraz bardziej heterogenicznej rzeczywistości, jak i specyfiki gdańskiej insertywnej tożsamości. Na wybudowanie czeka nowa siedziba Muzeum Gdańska. Z pewnością przydałyby się rewaluacja i aktualizacja wystaw stałych w poszczególnych oddziałach Muzeum Gdańska, Muzeum Archeologicznego czy Muzeum Morskiego. Niewątpliwie, obok jeszcze niewybudowanych czy nie do końca zdefiniowanych placówek (jak choćby wspomniany już Dom Daniela Chodowieckiego i Güntera Grassa), szereg już istniejących i od lat działających gdańskich instytucji kultury znajduje się w pewnego rodzaju zawieszeniu pomiędzy starą a nową pamięcią. Ta pierwsza często reprezentuje tradycje polskie o korzeniach słowiańskich, kulturowo homogeniczne i nastawione na minioną historię. Ta druga zaś podkreśla wielokulturowość, otwartość, różnorodność głosów i dyscyplin za pomocą wielostronnej narracji. Wydaje się, że gdańskie instytucje kultury znajdują się w momencie przejściowym pomiędzy wdrażaniem nowego dyskursu o pamięci a przywiązaniem do symboli tych narracji, od których powoli się odstępuje.

Symbolicznym krokiem w procesie ewolucji, ale także oswajania pamięci kulturowej współczesnych gdańszczan w ramach działalności gdańskich instytucji kultury jest w moim przekonaniu zmiana nazwy kluczowego dla gdańskiej tożsamości muzeum. Od końca 2017 r. Muzeum Historyczne Miasta Gdańska funkcjonuje pod nazwą Muzeum Gdańska. Zmiana nazewnictwa muzeum $\mathrm{w}$ istocie jest następstwem planów związanych z budową jego nowoczesnej siedziby. Ja jednak postrzegam tę zmianę także jako konsekwencję transformacji myślenia o Gdańsku, zachodzącej w ścisłej zależności z założeniami najnowszej strategii rozwoju miasta, będącego organizatorem muzeum. Przykład muzeum ilustruje rodzącą się tendencję do rewizji i autorefleksji myślenia o tożsamości Gdańska i jego pamięci kulturowej, której trzonem dwadzieścia lat temu były historyczność i opieka nad zabytkami. Obecnie zaś głównym priorytetem kulturalnym jest umocnienie nowoczesnej postawy obywatelskiej, wspieranie wizerunku nowego świadomego, przedsiębiorczego i otwartego mieszczanina, który będzie świadomie uczestniczył w procesie budowania nowej pamięci i tożsamości miasta. A przede wszystkim ugruntowanie tożsamości samego miasta, postrzeganego z nowoczesnej, demokratycznej i nienaznaczonej żadną reżimową ideologią perspektywy. Zadaniem stojącym przed twórcami wystawy stałej oraz nowego gmachu Muzeum Gdańska będzie zapewne - już po jego wybudowaniu - uprawomocnienie i utrwalenie tej wizji. Pozostaje mieć nadzieję, że nowe muzeum zmierzy się ze wszystkimi aspektami złożonej

99 Karkowska, Pamięć kulturowa..., s. 223. 
gdańskiej pamięci, a także zdoła pomieścić tę jej część, która należy do jej wielkich współtwórców, dotąd nieobecnych w narracjach muzeów gdańskich.

\section{Bibliografia}

Assmann Aleida, Wprowadzenie: o krytyce, popularności i adekwatności terminu „pamięć" [w:] Między historiq a pamięcia. Antologia, red. Magdalena Saryusz-Wolska, Warszawa 2013, s. 9.

Assmann Jan, Pamięć kulturowa. Pismo, zapamiętywanie i polityczna tożsamość w cywilizacjach starożytnych, tłum. Anna Kryczyńska-Pham, wstęp i red. nauk. Robert Traba, Warszawa 2016.

Bauman Zygmunt, Nieco plynnych myśli o sztuce w plynie, przeł. Adriana Kunka [w:] idem, Między chwila a pięknem o sztuce w rozpędzonym świecie, Łódź 2010, s. 20.

Bennett Tony, The Birth of the Museum. History, theory, politics, Routledge-London-New York 1995.

Bhabha Homi K., Culture's In-Between [w:] Questions of Cultural Identity, red. Stuart Hall, Paul du Gay, London-Thousand Oaks-New Dehli 1996, s. 54-55.

Chwin Stefan, Mity i prawdy nowej gdańskiej pamięci [w:] Gdańskie tożsamości. Eseje o mieście, red. Basil Kerski, Gdańsk 2014, s. 223.

Friedrich Jacek, Odbudowa Głównego Miasta w Gdańsku w latach 1945-1960, Gdańsk 2015.

Friedrich Jacek, Polskość? Niemieckość? Gdańskość? O tożsamości sztuki i architektury Gdańska w XIX i XX wieku [w:] Gdańskie tożsamości. Eseje o mieście, red. Basil Kerski, Gdańsk 2014, s. 55-81.

Friedrich Jacek, Walka obrazów. Przedstawienia wobec idei w Wolnym Mieście Gdańsku, Gdańsk 2018.

Gay Paul du, Organizing Identity: Entrepreneurial Governance and Public Management [w:] Questions of Cultural Identity, Questions of Cultural Identity, red. Stuart Hall, Paul du Gay, London-Thousand Oaks-New Dehli 1996, s. 152.

Gdańsk 2030 Plus Strategia rozwoju miasta, przyjęta uchwałą nr LVII/1327/14 Rady Miasta Gdańska z dnia 25 września 2014 r.

Gra resztkami (wywiad z Jeanem Baudrillardem przeprowadzony przez Salvatore Mele i Marka Titmarsha) [w:] Postmodernizm a filozofia, red. Stanisław Czerniak, Andrzej Szahaj, Warszawa 1996, s. 205, 226.

Halbwachs Maurice, Społeczne ramy pamięci, przeł. Marcin Król, Warszawa 1969.

Hobsbawm Eric, Introduction: Inventing Traditions [w:] Eric Hobsbawm, Terence Ranger, The Invention of Tradition, Cambridge 1983, s. 9-13.

http://development.cappellagedanensis.pl/.

http://ikm.gda.pl/idea/.

Kapralski Sławomir, Pamięć, przestrzeń, tożsamość. Próba refleksji teoretycznej [w:] Pamięć, przestrzeń, tożsamość, red. Sławomir Kapralski, Warszawa 2010, s. 9-10.

Karkowska Marta, Pamięć kulturowa mieszkańców Olsztyna lat 1945-2006 w perspektywie koncepcji Aleidy i Jana Assmannów, Warszawa 2014.

Kryszk Radosław, Załęcki Jarosław, Świadomość historyczna i tożsamość gdańszczan, „Rocznik Gdański” 1996, t. 56, z. 2, s 77-91.

Loew Peter Oliver, Gdańsk. Biografia miasta, przeł. J. Górny, Gdańsk, 2013. 
Loew Peter Oliver, Historia szuka pamięci [w:] Gdańskie tożsamości. Eseje o mieście, red. Basil Kerski, Gdańsk 2014, s. 143-148.

Loew Peter Oliver, Trzy mity. Niemieckość, polskość, wielokulturowość [w:] Gdańskie tożsamości. Eseje o mieście, red. Basil Kerski, Gdańsk 2014, s. 155.

Macdonald Sharon, Memorylands. Heritage and Identity in Europe Today, RoutledgeLondon-New York 2013.

Macdonald Sharon, Theorizing museums: an introduction [w:] Theorizing museums. Representing identity and diversity in a changing world, red. Sharon Macdonald i Gordon Fyfe, Oxford 1996, s. 138, 144.

Melosik Zbyszko, Szkudlarek Tomasz, Kultura, tożsamość i edukacja. Migotanie znaczeń, Kraków 2009.

Michałowski Lesław, Trójmiasto. Jedna przestrzeń, trzy mity [w:] Pamięć, przestrzeń, tożsamość, red. Sławomir Kapralski, Warszawa 2010, s. 258.

Modi memorandi. Leksykon kultury pamięci, red. Magdalena Saryusz-Wolska i Robert Traba, Warszawa 2014.

Muzeum II Wojny Światowej: katalog wystawy głównej, oprac. Rafał Wnuk, Paweł Machcewicz, Oliwia Gałka-Olejko, Łukasz Jasiński, Jan Daniluk, Gdańsk 2016.

Nora Pierre, Entre Mémoire et Histoire. La problématique des lieux [w:] Les Lieux de Mémoire, t. 1, La République, red. Pierre Nora, Paryż 1984, s. 34.

Ostow Robin, Introduction: Museums and National Identities in Europe in the Twenty-First Century [w:] Revisualizing National history, red. Robin Ostow, Toronto 2008, s. 3-4.

Poszerzenie pola kultury. Diagnoza potencjału sektora kultury w Gdańsku, red. Sławomir Czarnecki, Maciej Dzierżanowski, Martyna Grabowska, Jakub Knera, Lesław Michałowski, Cezary Obracht-Prondzyński, Krzysztof Stachura, Stanisław Szultka, Piotr Zbieranek, Gdańsk 2012.

Ricoeur Paul, Pamięć, historia, zapomnienie, przeł. Janusz Margański, Kraków, 2007.

Strategia rozwoju miasta Gdańska do roku 2010, przyjęta uchwałą Rady Miasta Gdańska nr LXII/868/98 z dnia 17 czerwca 1998 r.

Strategia rozwoju miasta Gdańska do roku 2015, przyjęta uchwałą Rady Miasta Gdańska Nr XXXIII/1011/04 z dnia 22 grudnia 2004 r.

Szczepański Marek S., Podróże po mniejszym niebie. Ojczyzna prywatna w oglądzie socjologicznym [w:] Tożsamość miejsca i ludzi. Gdańszczanie i ich miasto w perspektywie historyczno-socjologicznej, red. nauk. Małgorzata Dymnicka, Zbigniew Opacki, Gdańsk 2003, s. 142-143.

Trupinda Janusz, Muzeum Poczty Polskiej w Gdańsku. Przewodnik, Muzeum Historyczne Miasta Gdańska, Gdańsk 2017.

Woźniak Michał, Ochrona dziedzictwa kulturowego, a muzea Pomorza Nadwiślańskiego [w:] Muzea, a dziedzictwo kulturowe Pomorza. Materiały konferencji jubileuszowej, Wejherowo, 24 X 1998, red. Józef Borzyszkowski, Wejherowo-Gdańsk 2000, s. 18.

\section{Gdańsk's Cultural Institutions as Places of (Which?) Memory}

The article contains reflections on the cultural image of Gdańsk and its cultural institutions as they near the mark of thirty years of self-governance. On the basis of the analysis of aspects connected with some of the themes derived from permanent 
exhibitions presented at selected cultural institutions in Gdańsk, an attempt is undertaken to highlight the problems and phenomena which remain in close connection with the processes of constructing the post-communist cultural identity of the city. Among the crucial factors which are subject of the analysis first and foremost mention has to be instytucje kultury... made of the specificity of the local memory and identity which can be referred to as insertive, yet with the dominant tendency towards historicism. Those features, in turn, lead to describing some of the cultural institutions as places of memory, both with reference to their architecture, as well as to the narratives they present. An important place in the course of those deliberations is assigned to Gdańsk's cultural policy and its role in programming the local memory and identity, presented on the basis of the analysis of the development strategies published by the city over the analysed period of time. The state of events in Gdańsk is finally juxtaposed with popular trends in the development of new museology in Europe, where tendencies towards increasing introspection, revision, and anthropological approach can be observed. 